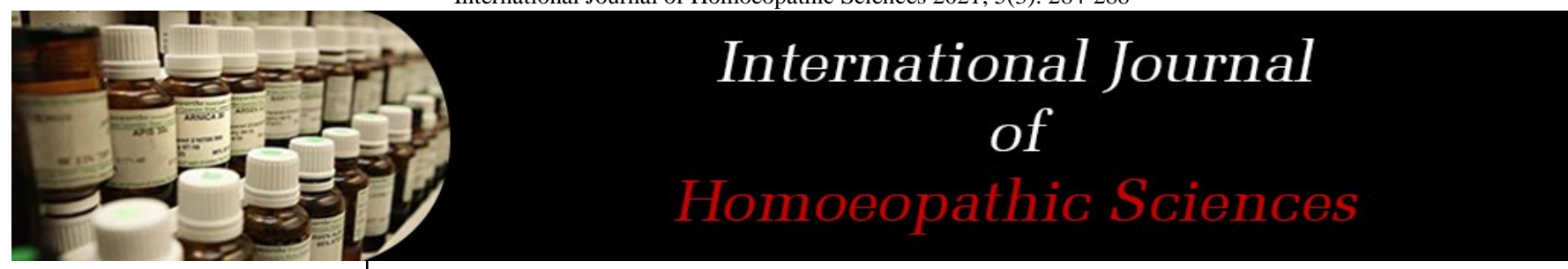

E-ISSN: $2616-4493$

P-ISSN: 2616-4485

www.homoeopathicjournal.com

IJHS 2021; 5(3): 284-288

Received: 03-05-2021

Accepted: 04-06-2021

Dr. Vishnu TM

Assistant Professor,

Department of Anatomy

Medical College and Hospital

Yenepoya Deemed To Be

University, Mangalore

Karnataka, India

Dr. Sushrutha K

Department of Homoeopathic

Pharmacy Yenepoya

Homoeopathic, Medical

College and Hospital

Yenepoya Deemed To Be

University, Mangalore

Karnataka, India
Yenepoya Homoeopathic,

Assistant Professor,

\section{Miasmatic evolution in polycystic ovarian syndrome with reportorial analysis}

\author{
Dr. Vishnu TM and Dr. Sushrutha K \\ DOI: https://doi.org/10.33545/26164485.2021.v5.i3d.434
}

Abstract

Polycystic Ovarian Syndrome (PCOS) is a common endocrinopathy typified by oligo-ovulation or anovulation, signs of androgen excess, and multiple small ovarian cysts. In case of Polycystic Ovarian Syndrome, it is the Psoric miasm which initially brings about functional changes followed by involvement of Sycotic miasm which leads to cystic changes in ovary. Polycystic Ovarian Syndrome, therefore, is the result of combinations of Psoric and Sycotic miasms in the sick individual, which through neuro-hormonal pathway, leads to imbalance of hormones and formation of cysts. The reportorial it is been emphasized with best possible rubrics which can be used while treating Polycystic Ovarian Syndrome.

Keywords: Polycystic Ovarian Syndrome (PCOS), miasm, psoric, sycotic, repertory

\section{Introduction}

Polycystic ovarian condition is the presence of different growths in ovaries which happen when standard changes of an ordinary period are upset. This heterogeneous problem is portrayed by inordinate androgen creation by the ovaries predominantly, which meddles with the conceptive, endocrine and metabolic capacities ${ }^{[1]}$.

PCOS influences for the most part of conceptive age. It influences $10 \%$ of ladies of conceptive age bunch. An expected $5-10 \%$ ladies of childbearing age have PCOS. It is pervasive in youthful conceptive age bunch (20-30\%) ${ }^{[2]}$.

Irving Frailer Stein (1887-1976) and Michael Leo Leventhal (1901-1971), American gynecologist was the distributer of primary portrayal of polycystic ovary disorder in 1935 . PCOS is otherwise called Stein Leventhal Syndrome. The soonest distributed portrayal of an individual with what is presently perceived as PCOS was in 1721 in Italy. Growth related changes to the ovaries were portrayed in $1844^{[3]}$.

\section{Definition}

According to Williams's gynecology: "PCOS is a common endocrinopathy typified by oligo-ovulation or anovulation, signs of androgen excess, and multiple small ovarian cysts". ${ }^{4}$

According to Shaw's textbook of gynaecology: "Polycystic ovarian syndrome is a multisystem endocrinopathy with ovarian expression of metabolic disturbance and a wide spectrum of clinical features, such as hyperandrogenism and obesity along with metabolic disorders" [5]

According to Salhan Sudha's textbook of gynaecology: "Polycystic ovarian syndrome is a complex endocrine disorder characterized by chronic anovulation and androgen excess with clinical manifestations of irregular cycles, hirsutism, acne and obesity" [6].

\section{Clinical Features}

Dr. Vishnu Tm

Assistant professor

Department of anatomy

Yenepoya homoeopathic medical college \& hospital Yenepoya deemed to be university, Mangalore Karnataka, India
Menstrual abnormalities

- Oligomenorrhea

- Amenorrhoea

Central Obesity

- $\quad$ BMI $>30 \mathrm{~kg} / \mathrm{cm}$
- Episodic menometrorrhagia with anemia. 
- Waist line > 35"

- Infertility

- Hirsutism

- Acne

- Seborrhoea ${ }^{[7]}$.

- Acanthosis nigricans Hair- An- syndrome: characterised by the hyper androgenism, insulin, resistance and acanthosis nigrcans ${ }^{[8]}$.

- Increased first trimester miscarriage

- Androgenic alopecia

- Increased terminal (coarse) hair growth in midline structures (face, neck, and abdomen).

\section{Virilization}

- Clitoromegaly

- Deepening of the voice

- Temporal balding or masculisation of body habitus. ${ }^{9}$

- Decreased breast size

- Recurrent spontaneous abortion.

\section{Other Symptoms Include}

- Exhaustion or lack of mental alertness.

- Sleep apnea or excessive snoring.

- Thyroid problems.

- Virilization (20\%) ${ }^{[10]}$.

- Skin tags or tiny excess flaps of skin in the armpits or neck area.

- Midcycle pain indicating painful ovulation due to the enlargement and blockage of the surface of the ovaries.

- HAIR-AN syndrome: Characterized by hyperandrogenism, insulin resistance, acanthosis nigricans ${ }^{[2]}$.

- Psychological problems: Emotional wellness issues including bipolar turmoil and gorging issue additionally happen all the more regularly in ladies with PCOS. Studies have detailed that ladies who have PCOS are more inclined to misery, uneasiness, low confidence, negative self-perception, and psychosexual brokenness, negative effect of state of mind aggravation, helpless confidence and diminished mental prosperity on inspiration and on capacity to carry out and support fruitful way of life changes ${ }^{[11]}$

\section{Homoeopathic Review of Literature}

Homoeopathy can be defined as a system of therapeutics based on the law of similar. A successful application of the law of similar rests entirely on the ability of the prescriber to identify a portrait in the picture gallery of the homoeopathic materia medica as exactly similar to the portrait of the disease as revealed by the patient ${ }^{[12]}$.

\section{Polycystic Ovarian Disease-Homoeopathic Perspective}

A woman's most vulnerable region frequently is by all accounts associated with her reproductive system and its related hormones, the system is sensitive however it is regularly treated rather gracelessly by current medication. Numerous issues can be settled by protected homeopathic treatment, just as by dietary change, for non-steady conditions ${ }^{[13]}$.

According to homeopathic philosophy, it is the individual in general who is debilitated regardless of whether her organ seems, by all accounts, to be influenced by the illness cycle. The patient, in this way must be dealt with comprehensively, as such, psychosomatically. The patient in infection must be thought of and not the sickness in quiet. Such methodology of treatment eliminates the impact of illness (pathology) yet in addition demolishes the reason for sickness (etiology) prompting perpetual recuperation of wellbeing. Repeat of infection can likewise be evaded by comprehensive method of treatment. The most incessant area of the sycotic appearances in ladies is in the pelvic organs and the more persistent sorts incorporates the cystic degeneration of ovaries ${ }^{[14]}$.

\section{Master Hahnemann Says}

"True natural chronic diseases owe their origin to chronic miasm, constantly extending and without carefully regulating mental and bodily functions, they will never tend to cease the suffering till the end of his life" $(\S 78)^{[15]}$.

Chronic diseases, according to Hahnemann, are produced due to three basic miasmatic constitutional disturbances or chronic miasm. The chronic miasms giving rise to all forms of chronic disease are psora, syphilis, sycosis.

Further, he mentioned the chronic latent psoric state as a 'sleeping' chronic disease which can be awakened by incidents and life circumstances like excessive hardships, laboring in swamps, bodily injuries, and wounds, excess of cold or heat and even the unsatisfied hunger of poverty. But much more injurious and triggering the latent chronic state to the outbreak of chronic disease manifestations are emotional disturbance or incidents such as an unhappy marriage, remorseful conscience, change of fortune, sudden death of son or melancholy from disappointment in love. The incident is due to the life circumstances of the patient and the chronic state is due to the patient's constitutional predisposition and the inherited pathological miasmatic tendencies ${ }^{[16]}$.

\section{HA Roberts Says}

"When some external manifestation occurs, such as a catarrhal condition, a leucorrhoea, or even the return of the menstrual period, there is a general amelioration of the mental condition" [14]

The most frequent location of the sycotic manifestations in women is in the pelvic organs. In the more chronic types, we get cystic degeneration of ovaries, the uterus \& the fallopian tubes. Sycosis attacks the internal organs, especially the pelvic \& sexual organs in the forms of inflammation, infiltration of the tissues, hypertrophies, cystic degeneration; when thrown back into the system by suppression this stigma causes dishonesty, moral degeneracy and mania ${ }^{[14]}$.

In the footnote of aphorism 94 of Organon of medicine, Hahnemann mentioned in detail the points to be noted in case taking of chronic diseases of females. Proper casetaking, analysis and evaluation of case followed by repertorization is the ideal homoeopathic approach ${ }^{[15]}$.

\section{Miasmatic Concept}

In case of PCOS, it is the psoric miasm which initially brings about functional changes followed by involvement of sycotic miasm which leads to cystic changes in ovary. PCOS, therefore, is the result of combinations of psoric and sycotic miasms in the sick individual, which through neurohormones pathway, leads to imbalance of hormones and formation of cysts. If syphilitic miasm also unites with both two, it leads to various malignant processes and ultimately to cancer pathology. 
Miasmatic Background of Polycystic Ovarian Disease

\begin{tabular}{|c|c|c|c|c|}
\hline & PSORA & SYCOSIS & SYPHITIS & TUBERCULAR \\
\hline & $\begin{array}{c}\text { Functional disturbance of ovaries } \\
\text { and uterus }{ }^{[17]} \text {. especially } \\
\text { amenorrhoea of functional orign } \\
{[18] \text {. }}\end{array}$ & $\begin{array}{c}\text { Inflammation and cystic } \\
\text { degeneration of ovaries and } \\
\text { fallopian tube etc. any tumor } \\
\text { formation of ovaries and } \\
\text { fallopian tube etc }{ }^{[17]} \text {. } \\
\text { Polycystic disease of the ovaries } \\
\text { [18]. }\end{array}$ & & $\begin{array}{l}\text { Symptoms associated with } \\
\text { bleeding disorders }{ }^{[17]} \text {. }\end{array}$ \\
\hline Pain & $\begin{array}{l}\text { Dysmenorrhoea especially at } \\
\text { puberty with sharp pains }{ }^{[17]} \text {. }\end{array}$ & $\begin{array}{l}\text { Spasmodic, colicky and } \\
\text { paroxysmal pains }{ }^{[17]} \text {. }\end{array}$ & $\begin{array}{c}\text { Menses are characterized } \\
\text { by bone pains and lumbago } \\
{[18] .}\end{array}$ & $\begin{array}{l}\text { May not be painful but always } \\
\text { exhaustive }^{[17]} \text {. }\end{array}$ \\
\hline Discharges & Bland and scanty ${ }^{[18]}$. & $\begin{array}{c}\text { Acrid, painful, and with pruritis. } \\
\text { Blood is offensive, clotted, and } \\
\text { stringy, clots are large and dark. } \\
\text { [17]. } \\
\text { Profuse }{ }^{[18]} \text {. }\end{array}$ & $\begin{array}{l}\text { Acrid, putrid and offensive } \\
{[18] .}\end{array}$ & $\begin{array}{l}\text { Flow is watery and long } \\
\text { lasting and rarely offensive } \\
\text { [17]. profuse and blood tinged } \\
\text { or hemorrhagic can be } \\
\text { associated with clots }{ }^{[18]} \text {. }\end{array}$ \\
\hline Face & $\begin{array}{c}\text { Face has dry, itching pimple and } \\
\text { simple acne }{ }^{[18]} \text {. }\end{array}$ & $\begin{array}{l}\text { Face can be pale, bluish and } \\
\text { dropsical }{ }^{[18]} \text {. }\end{array}$ & Hard acne on the face ${ }^{[18]}$. & $\begin{array}{l}\text { Bloated appearance of face, } \\
\text { especially after sleep }{ }^{[18]} \text {. }\end{array}$ \\
\hline Infertility & $\begin{array}{c}\text { Impotency and sterility from lack } \\
\text { of sexual desire, without any } \\
\text { organic defect in the sexual parts } \\
{[18] \text {. }}\end{array}$ & $\begin{array}{c}\text { Incapability to conceive due to } \\
\text { various factors including } \\
\text { hormone imbalance. Sterility and } \\
\text { infertility result from pelvic } \\
\text { inflammatory disease and other } \\
\text { conditions such as endometriosis } \\
\text { [18]. }\end{array}$ & $\begin{array}{l}\text { Possible failure to } \\
\text { discharge the ovum at } \\
\text { ovulation resulting in } \\
\text { infertility }{ }^{[18]} \text {. }\end{array}$ & $\begin{array}{c}\text { Infertility results from } \\
\text { prolonged menstrual bleeding } \\
{[18] .}\end{array}$ \\
\hline Skin & $\begin{array}{l}\text { Pimples with dryness and scurfy } \\
\text { scales }{ }^{[18]} \text {. }\end{array}$ & $\begin{array}{c}\text { Hyperpigmentation of the skin, } \\
\text { and melanomas. Disturbed } \\
\text { pigment metabolism, resulting in } \\
\text { hyper- pigmentation in patches or } \\
\text { diffused in different parts. Oily } \\
\text { skin }{ }^{[18]} \text {. }\end{array}$ & $\begin{array}{c}\text { Depigmentation of the skin } \\
{[18]}\end{array}$ & \\
\hline $\begin{array}{c}\text { General } \\
\text { manifestation }\end{array}$ & $\begin{array}{l}\text { Atrophy, ataxia, anaemia and } \\
\text { anoxemia. } \\
\text { Deficiency disorders. } \\
\text { Hypo- immunity }{ }^{[18]} \text {. }\end{array}$ & \begin{tabular}{|c|} 
Hypertrophy- growths and \\
incoordination. \\
Deposition, and/ or proliferation \\
of cells/ tissues. \\
Hyper- mental and physical ${ }^{[18]}$.
\end{tabular} & $\begin{array}{l}\text { Dystrophy, degeneration } \\
\text { Destruction- physical and } \\
\text { mental. } \\
\text { Deformities and fragility } \\
\text { [18]. }\end{array}$ & $\begin{array}{l}\text { Dystrophy with hemorrhage. } \\
\text { Dissatisfaction. } \\
\text { Depletion }{ }^{[18]} \text {. }\end{array}$ \\
\hline Nourishment & Does not assimilate well ${ }^{[18]}$. & Over nourishment ${ }^{[18]}$. & $\begin{array}{c}\text { Disorganized digestion. } \\
\{18] .\end{array}$ & $\begin{array}{c}\text { Patients crave the things } \\
\text { which make them sick }{ }^{[18]} \text {. }\end{array}$ \\
\hline
\end{tabular}

\section{Repertory in Clinical Practice}

The word repertory means a store house, a store collection of information. Every well proved drug has got thousands of symptoms and for a man of average intelligence, it is almost impossible to remember all the symptoms of the entire drug as well as to establish total correspondence between drugs and diseases. Repertory bridges the gulf between Materia Medica on one hand and disease on the other.
Repertory is a systematically and logically arranged index to homoeopathic Materia Medica, which is loaded with data gathered from toxicology, drug demonstrating and clinical experience. The repertory encourages us to discover the necessary indications, along with the medication or a bunch of meds having various evaluations. It is an associating join between the Materia Medica and sickness ${ }^{[19]}$. 


\section{Different Observations about Repertory}

\begin{tabular}{|c|c|}
\hline Repertory & Rubrics \\
\hline Kent's Repertory of Homoeopathic Materia Medica ${ }^{[20]}$ & - $\quad$ Genitalia- female-Tumors- ovaries- cyst \\
\hline $\begin{array}{l}\text { Knerr Repertory of Hering's Guiding Symptoms Of Our } \\
\text { Materia Mediea }{ }^{[21]}\end{array}$ & $\begin{array}{l}\text { - } \quad \text { Female Sexual Organs- ovaries- tumors } \\
\text { - } \quad \text { Female Sexual Organs- ovaries- pain (undefined)- right, in (ovarian cyst)- } \\
\text { - } \quad \text { Female Sexual OrgaNS- ovaries- sensitive (tender) - right, with ovarian cyst } \\
\text { - Female Sexual Organs- ovaries- tumors- cyst, with pain in abdomen upon } \\
\text { straightening up, walks bent, with hand pressed to painful side } \\
\text { Female Sexual Organs- ovaries- tumors- cyst, size of a head, since six years } \\
\text { Female Sexual Organs- ovaries- tumors- cyst, measurement taken in a line } \\
\text { over crests of ilium shows increase in size of ten inches. } \\
\text { Female Sexual Organs- ovaries- tumors- large cyst, supposed to be connected } \\
\text { with left ovary, occupying space between rectum, uterus and vagina, so as to } \\
\text { obliterate posterior cul de sac and almost occlude vagina } \\
\text { Female Sexual Organs- ovaries- tumors- voluminous cyst in right } \\
\text { Female Sexual Organs- ovaries- tumors- cyst, strained herself lifting after } \\
\text { appearance of tumor } \\
\text { - } \quad \text { Female Sexual Organs- ovaries- tumors- cyst, after tapping } \\
\text { Female Sexual Organs- ovaries- tumors- cyst, tapped twice } \\
\text { Female Sexual Organs- ovaries- tumors- with urinary difficulties (cyst) }\end{array}$ \\
\hline Clarke’s- Clinical Repertory ${ }^{[22]}$ & $\begin{array}{l}\text { Ovaries- cysts of, } \\
\text { Ovaries- Diseases of } \\
\text { Ovaries- dropsy of }\end{array}$ \\
\hline Complete Repertory ${ }^{[23]}$ & - $\quad$ Female - Tumors - Ovaries - Cysts: \\
\hline A Synoptic Key Of The Materia Medica ${ }^{[24]}$ & - $\quad$ Generalities - Cysts \\
\hline A Concise Repertory of Homoeopathic Materia Medica & - $\quad$ Ovaries- cystic \\
\hline $\begin{array}{l}\text { Pocket Manual Of Homoeopathic Materia Medica \& } \\
\text { Repertory }{ }^{[26]}\end{array}$ & - $\quad$ Female Sexual System - Ovaries - Cysts - dropsy \\
\hline Boger Boennighausan Characteristic Repertory ${ }^{[27]}$ & - $\quad$ Genitalia - Female organs - cysts \\
\hline Homoeopathic Medical Repertory ${ }^{[29]}$ & $\begin{array}{ll}\text { - } & \text { Female - Cysts, genitalia - cysts, ovarian } \\
\text { - } & \text { Female - Cysts, genitalia - cysts, ovarian - left } \\
\text { - } & \text { Female - Cysts, genitalia - cysts, ovarian - right } \\
\end{array}$ \\
\hline Ward’s repertory ${ }^{[30]}$ & $\begin{array}{l}\text { - Congestion - Sensation as of swelling and congestion of ovaries- with pain as } \\
\text { if from a corrosive tumor }\end{array}$ \\
\hline Gentry ’s repertory [31] & $\begin{array}{ll}- & \text { Ovary-tumors or cysts of } \\
& \text { Ovary-cyst in region of left ovary }\end{array}$ \\
\hline Scholten’s repertory ${ }^{\{32]}$ & $\begin{array}{l}\text { - } \quad \text { Genital female-ovaries-cyst } \\
\text { Genital female-ovaries-cyst-left }\end{array}$ \\
\hline Khullar’s repertory ${ }^{[33]}$ & - $\quad$ Breast-sore-pain-menses-absent with \\
\hline Minton H. Uterine therapeutics ${ }^{[34]}$ & 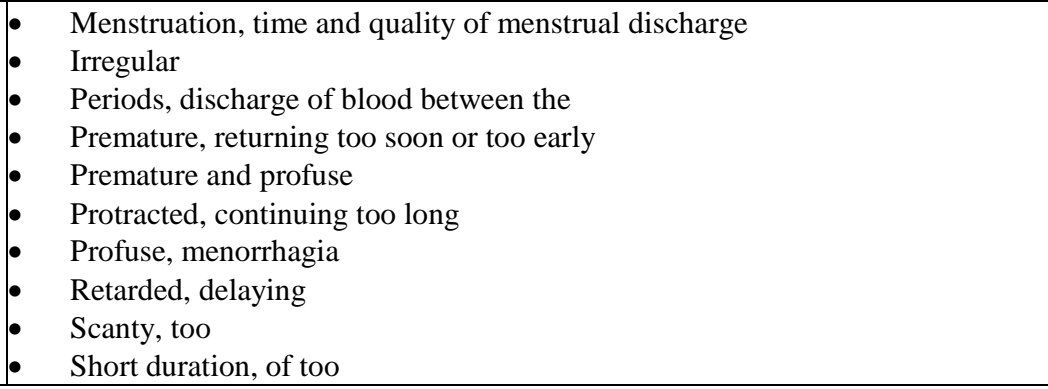 \\
\hline
\end{tabular}

\section{Homoeopathic Therapeutics}

Common remedies covering the symptoms of PCOD are Sepia, Pulsatilla, Calcarea Carb, Natrum Mur, Thuja, Pulsatilla, Kali Carb, Senecio, Euphrasia, Coccus Cacti, Psorinum, Sulphur, Silicea, Graphites and Ammonium Carb [35].

\section{Conclusion}

In day today practice most of the homoeopathic physicians are having either therapeutic approach or single remedy single dose approach. But it is not always that we consider Miasm or Repertory while treating this syndrome. This study is an effort to make the readers understand the importance of miasmatic evolution in PCOS which will help us to achieve possible miasmatic diagnosis. In the section of reportorial approach we have highlighted with best possible rubrics which can be selected or referred while treating PCOS. This is a genuine effort to understand and practice in 
the best possible rational way.

\section{References}

1. Chaudhuri snehamay. Essentials in gynaecology. CBS publishers \& distributors' pvt Ltd; first edition 2015, 96-100.

2. Dutta DC. Textbook of Gynaecology (including contraception). $5^{\text {th }}$ ed. Kolkatta: New central book agency (P) ltd; 2001, 421-571.

3. Berek. Jonathan S. Berek \& Novak's gynecology. wolters kluwer india pvt Ltd; fifteenth edition 1075.

4. Hoffman Barbara L et al. Williams gynecology. China: Mc Graw- hill companies, Inc; second edition 460.

5. Padubidri VG, Daftary Shirish N, Howkins Bourne. Shaw's textbook of gynaecology. Elsevier a division of reed Elsevier India Pvt Ltd; $14^{\text {th }}$ edition 331- 333.

6. Salhan sudha. Textbook of gynecology. jaypee brothers medical publishers (p) ltd; first edition 2011, 72.

7. Balakrishnan Sheila. Clinical case discussions in obstetrics and gynaecology. Hyderabad: paras medical publisher; first edition 2011, 170-172.

8. Dutta DC. Textbook of gynaecology. Calcutta: new central book agency (p) Ltd; $4^{\text {th }}$ reprint edition 421.

9. Arvind Rao kamini. Text book of gynaecology. Elsevier a division of reed Elsevier India pvt Ltd; first edition 2008, 133-138.

10. McPhee Stephen J, Papadakis Maxine A, Rabow Michael W. Current medical diagnosis and treatment.51th edition. McGraw Hill Lange 2012, 7451133.

11. Fauci Anthony S, Kasper Dennis L, Longo Dan L, Braunwald Eugene, Hauser Stephen L, Jameson Larry $\mathrm{J}$, et al. Harrison's principles of internal medicine. $17^{\text {th }}$ edition: The Mcgraw -Hill Companies 2008, 301.

12. Dhawale ML. Principles \&practice of homoeopathy. Mumbai: Dr. M.L. Dhawale memorial trust; fifth reprint edition 2008;3:195.

13. Suvarna BS. Women's health problems and homoeopathic treatment. Homoeopathy for all. September 2008;19(4):47.

14. Roberts Herbert A. The principles and art of cure by Homoeopathy. $3^{\text {rd }}$ edition. New Delhi: B.Jain publishers (P) ltd 2005, 239-247

15. Hahnemann Samuel. Organon of Medicine. $5^{\text {th }} \& 6^{\text {th }}$ Edition. New Delhi: B. Jain Publishers 2002, 70.

16. Hahnemann S. The Chronic Diseases, Their Peculiar Nature and Their Homoeopathic Cure: 1st Edition. B. Jain Publishers Pvt. Ltd, 2008, 43.

17. Rajendran ES. The nucleus lectures on chronic diseases and miasms. Calicut: Mohna publications. Reddy E, Sharma PK, Raj PP. A clinical study on effect of Plantago in gingivitis by assessing bleeding and plaque index first edition 2004, 145-146.

18. Kumar Banerjea Subrata. Miasmatic prescribing. New Delhi: B. Jain publishers (p) Ltd; Second extended edition 2006, 67-143.

19. Tiwari Shashi Kant. Essentials of repertorization. $5^{\text {th }}$ edition. New Delhi: B.Jain publishers (P) Ltd 2012;(57):473-474.

20. Kent JT. Repertory of the Homoeopathic Materia Medica, B. Jain Publishers Pvt. Ltd, New Delhi, Reprint edition 2002, 745.

21. Calvin Knerr B. Repertory of Hering's Guiding Symptoms of Our Materia Medica, export edition reprint edition B. Jain publishers (P) ltd, New Delhi 2000, 1130-1137.

22. Clarke J. A clinical repertory to the Dictionary of materia medica. 11th ed. Bradford: Health Science Press 1971, 87.

23. Zandvoort Van Roger. The Complete Repertory. Reprint Edition, Institute for Research on Homoeopathic Information and Symptomatology 1998. (RADAR OPUS)

24. Boger CM. A Synoptic Key to the Materia Medica, Jain Publishers (P) Ltd”. New Delhi. Aug 2002, 34.

25. Phathak SR. A Consise Repertory of Homoeopathic Medicines, 4th edition re-print, B. Jain Publishers, New Del hi, India 2009, 296-297

26. Boericke William MD. New Manual Of Homoeopathic Materia Medica With Repertory, BJain Publishers, New Delhi, 44 ${ }^{\text {th }}$ impression 2019, 771

27. Boger CM. Bonninghausen's Characteristics \$ Repertory. B. Jain Publishers (P) Ltd. New Delhi. 49 impression 2019, 659.

28. Schroyen's Frederik. Synthesis Repertorium Homoeopathicum syntheticum9.1. (RADAR OPUS) New Delhi, India. B.Jain Publishers Pvt. Ltd 2016.

29. Murphy Robin ND. Homoeopathic Medical Repertory. 3 rd Revised Edition. New Delhi, India. B. Jain Publishers Pvt. Ltd 2011, 764.

30. Ward JW. The Unabridged Dictionary Of Sensations As if ", Reprint edition, Bjain Publishers, New Delhi 2006, 190

31. Gentry WD. The Concordance Repertory of the Materia Medica” Volume 4, B Jain Publishers Pvt. Ltd. New Delhi, Reprint Edition 1995, 145.

32. Jan Scholten and Roger Savage Repertory of the Elements edition 2004, 284.

33. Khullar RL. Repertory of Concomitant Symptoms” Hompath Zomeo LAN New Delhi, India. B.Jain Publishers Pvt. Ltd 2016.

34. Minton H. Uterine Therapeutics and its utility in common Obstetrics and Gynaecological conditions”, New Delhi: B. Jain 2005.

35. https://www.balanceintohealth.com/blog/top-12homeopathic-remedies-for-polycystic-ovariansyndrome-or-pcos 